\title{
Pemetaan Percepatan Tanah Maksimum dan Intensitas Gempa Kota Padang Menggunakan Rumusan Fukushima-Tanaka
}

\author{
Fitri Gustiana ${ }^{1, *}$, Dwi Pujiastuti ${ }^{1}$, Maya Minangsih ${ }^{2}$ \\ ${ }^{1}$ Jurusan Fisika Universitas Andalas \\ ${ }^{2}$ BMKG Padang Panjang \\ *gustianaipit@email.com
}

\begin{abstract}
ABSTRAK
Pemetaan nilai percepatan tanah maksimum (PGA) dan intensitas gempa di Kota Padang telah dilakukan menggunakan rumusan empiris Fukushima-Tanaka. Kota Padang digrid dengan spasi jarak $0,02^{\circ}$ untuk sumber gempa di Segmen Mentawai dan sekitarnya dari tahun 1976-2017. Perhitungan nilai percepatan tanah dilakukan pada setiap titik grid yang berjumlah 234 titik. Pemetaan dilakukan dengan memisahkan kejadian gempa sebelum dan sesudah gempa besar 30 September 2009. Nilai PGA sebelum gempa 30 September 2009 berkisar dari 48,27-94,2 gal dengan PGA terendah terdapat di Kecamatan Bungus Teluk dan PGA tertinggi di Kecamatan Koto Tangah. Nilai PGA sesudah gempa 30 September 2009 berkisar dari 76,10-96,58 gal dengan PGA terendah terdapat pada sebagian Kecamatan Bungus Teluk, sedangkan PGA tertinggi terdapat di Kecamatan Koto Tangah, Padang Utara, dan sebagian Kecamatan Padang Barat. Intensitas gempa sebelum gempa 30 September 2009 berskala VI MMI pada Kecamatan Bungus Teluk, Padang Selatan dan sebagian Padang Barat, Lubuk Begalung, dan Lubuk Kilangan, selain kecamatan tersebut berskala VII MMI. Intensitas gempa sesudah gempa 30 September 2009 berskala VII MMI pada semua kecamatan di Kota Padang. Hal ini menunjukkan terjadinya perluasan daerah dengan intensitas VII MMI di Kota Padang setelah gempa 30 September 2009.
\end{abstract}

Kata kunci: PGA, Fukushima-Tanaka, intensitas gempa, Segmen Mentawai

\begin{abstract}
Mapping of peak ground acceleration (PGA) and earthquake intensity in Padang City has been carried out using the empirical formula of Fukushima-Tanaka. Padang city was divided with a spacing of $0.02^{\circ}$ for the source of the earthquake in the Mentawai and surrounding segments from 1976-2017. Calculation the ground acceleration value is carried out at each grid point which is 234 points. The mapping was carried out by separating the occurrence of earthquakes before and after the big earthquake of September 30, 2009. The PGA values before the September 30, 2009 earthquake ranged from 48.27 to 94.2 gal with the lowest PGA found in Bungus Teluk District and the highest PGA in Koto Tangah District. PGA values after the September 30, 2009 earthquake ranged from 76.10 to 96.58 gal with the lowest PGA found in most of Bungus Teluk District, while the highest PGA was in Koto Tangah Subdistrict, North Padang, and part of West Padang District. The intensity of the earthquake before the earthquake on September 30, 2009 was on the scale of VI MMI in Bungus Teluk District, Padang Selatan and part of Padang Barat, Lubuk Begalung, and Lubuk Kilangan, besides the subdistrict of MMI scale VII. The intensity of the earthquake after the earthquake of September 30, 2009 was on the scale of VII MMI in all sub-districts in Padang City. This shows the occurrence of regional expansion with VII MMI intensity in Padang City after the September 30, 2009 earthquake.
\end{abstract}

Keywords: PGA, Fukushima-Tanaka, earthquake intensity, Mentawai Segment

\section{PENDAHULUAN}

Secara tektonik Kota Padang termasuk daerah paling rawan gempa di Indonesia, karena berada pada pertemuan lempeng Indo-Australia yang menunjam ke bawah lempeng Eurasia. Tunjaman tersebut membentuk tiga zona yang menjadi sumber gempa yaitu zona subduksi, Sesar Mentawai dan Sesar Sumatera (Sunarjo dkk., 2010). Wilayah Kota Padang merupakan bagian yang tidak terpisahkan dari sistem Sesar Sumatera. Kota Padang diapit oleh Sesar Sumatera yang terdapat pada bagian tengah Pulau Sumatera dan palung laut di sebelah baratnya, sehingga wilayah ini menjadi sangat rawan bencana gempa (Isra, 2010).

Gempa bumi dengan kekuatan yang cukup besar akan sangat berdampak pada kerusakan bangunan. Salah satu faktor yang dapat menentukan besar kecilnya kerusakan tersebut adalah percepatan tanah maksimum atau Peak Ground Acceleration (PGA) (Edwiza, 2008). Setiap gempa akan menghasilkan satu nilai percepatan tanah pada suatu tempat. Nilai percepatan tanah yang dibutuhkan untuk menyesuaikan kekuatan bangunan yang akan dibangun adalah percepatan tanah maksimum (Sunarjo dkk., 2010). Pemetaan nilai percepatan tanah 
maksimum akan menjadi informasi penting dalam menunjang pembangunan tata ruang dan wilayah di daerah-daerah rawan gempa (Kapojos dkk., 2015).

Nilai percepatan tanah dapat diketahui melalui dua cara yaitu pengukuran menggunakan alat ukur percepatan tanah atau akselerograf dan pendekatan secara empiris (Linkemer, 2008). Percepatan tanah menggunakan alat dapat dihitung secara langsung, namun cara ini sering terkendala akibat keterbatasan jaringan akselerograf baik dari segi ketersediaan alat, cakupan waktu, dan wilayah, maka diperlukan pendekatan secara empiris (Kapojos dkk., 2015). Pendekatan secara empiris dapat memberikan gambaran secara umum untuk percepatan tanah maksimum sesuai titik-titik yang dibutuhkan (Ibrahim dan Subarjo, 2004).

Beberapa rumusan yang bisa dipakai untuk menghitung nilai percepatan tanah secara empiris yaitu rumusan Mc.Guire, Fukushima-Tanaka, Donovan, dan Esteva (Edwiza dan Novita, 2008). Berdasarkan hasil validasi perhitungan percepatan tanah menggunakan ke-4 rumusan empiris tersebut dengan nilai percepatan tanah pada akselerograf di Stasiun Maritim Teluk Bayur, maka diperoleh bahwa rumusan Fukushima-Tanakalah yang paling cocok digunakan untuk Kota Padang (Pujiastuti dkk., 2018). Rumusan Fukushima-Tanaka diperoleh menggunakan 1372 komponen percepatan tanah maksimum horizontal dari 28 gempa di Jepang dan 15 gempa yang terjadi di Amerika. Rumusan ini banyak diterapkan di wilayah Jepang dengan Persamaan 1.

$$
\log (a)=0.41 M s-\log (R+0.032 * 100.41 M s)-0.0034 R+1.30
$$

$a$ merupakan nilai percepatan tanah maksimum (gal), $M_{S}$ adalah Magnitudo permukaan, dan $R$ adalah jarak hiposenter $(\mathrm{km})$. Adanya peristiwa gempa besar yang terjadi di Padang beberapa tahun belakangan seperti gempa 30 September 2009 tentu akan mempengaruhi percepatan tanah di Kota Padang, sehingga pada penelitian ini pemetaan PGA dan intensitas gempa Kota Padang akan dipisah menjadi dua bagian yaitu sebelum dan sesudah gempa 30 September 2009. Pemisahan ini dapat memberikan gambaran perubahan nilai percepatan tanah maksimum maupun intensitas gempa di Kota Padang setelah terjadinya gempa besar 30 September 2009.

\section{METODE}

Teknik pengolahan data pada penelitian ini yaitu data sekunder gempa bumi yang bersumber di Segmen Mentawai dan sekitarnya diunduh dari tahun 1976 sampai 2017 pada situs USGS. Selanjutnya, Kota Padang digrid dengan spasi jarak $0,02^{\circ}$. Jarak antara koordinat episenter ke masing - masing koordinat titik grid dihitung menggunakan Persamaan 2.

$$
\Delta^{2}=\left(X_{2}-X_{1}\right)^{2}+\left(Y_{2}-Y_{1}\right)^{2}
$$

$\Delta$ adalah jarak episenter ke koordinat daerah perhitungan $(\mathrm{km}), X$ adalah lintang daerah perhitungan ( derajat), dan $Y$ merupakan bujur daerah perhitungan (derajat). Jarak hiposenter dari setiap titik grid ke sumber gempa dihitung dengan Persamaan 3.

$$
R^{2}=\Delta^{2}+h
$$

$R$ adala jarak hiposenter $(\mathrm{km}), \Delta$ adalah jarak episenter ke koordinat daerah perhitungan $(\mathrm{km})$, dan $h$ adalah kedalaman gempa $(\mathrm{km})$. Nilai percepatan tanah dihitung pada setiap titik grid wilayah penelitian dari tahun 1976-2017 menggunakan rumusan empiris Fukushima-Tanaka pada Persamaan 1 . Selanjutnya nilai PGA ditentukan untuk data gempa sebelum dan sesudah gempa 30 September 2009. Nilai PGA juga dikonversi ke dalam skala Modified Mercalli Intensity (MMI) menggunakan Persamaan 4.

$$
M M I=2.86 \log (P G A)+1.24
$$

Langkah terakhir yaitu membuat peta percepatan tanah maksimum dan intensitas gempa Kota Padang sebelum dan sesudah gempa 30 September 2009 menggunakan Software Arcgis dan Surfer. 


\section{HASIL DAN DISKUSI}

\subsection{Percepatan Tanah Kota Padang}

\subsubsection{Percepatan Tanah Maksimum Kota Padang Sebelum Gempa 30 September 2009}

Banyaknya gempa yang terjadi dari tahun 1976 sampai 29 September 2009 ditunjukkan oleh peta seismisitas gempa pada Gambar 1. Jumlah data gempa yang diperoleh sebelum gempa 30 September 2009 adalah 173 data. Simbol lingkaran pada peta mewakili setiap kejadian gempa di wilayah tersebut. Semakin besar simbol lingkaran pada peta menunjukkan semakin besar pula magnitudo gempanya. Pada gambar terlihat sebaran gempa lebih rapat pada perairan sebelah timur Kepulaun Mentawai dekat Pagai Utara.

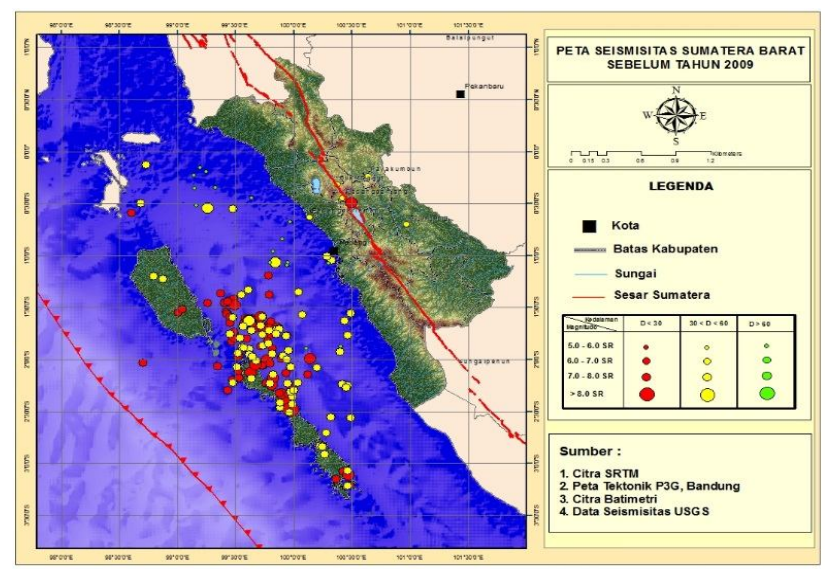

Gambar 1 Peta Seismisitas Gempa di Segmen Mentawai dan Sekitarnya Tahun 1976 sampai 29 September 2009

Nilai PGA dihitung untuk 173 data gempa tersebut menggunakan Persamaan 1 di setiap titik grid Kota Padang, sehingga dihasilkan peta percepatan tanah maksimum (PGA) Kota Padang wilayah Segmen Mentawai dan sekitarnya sebelum kejadian gempa besar 30 September 2009 seperti Gambar 2.

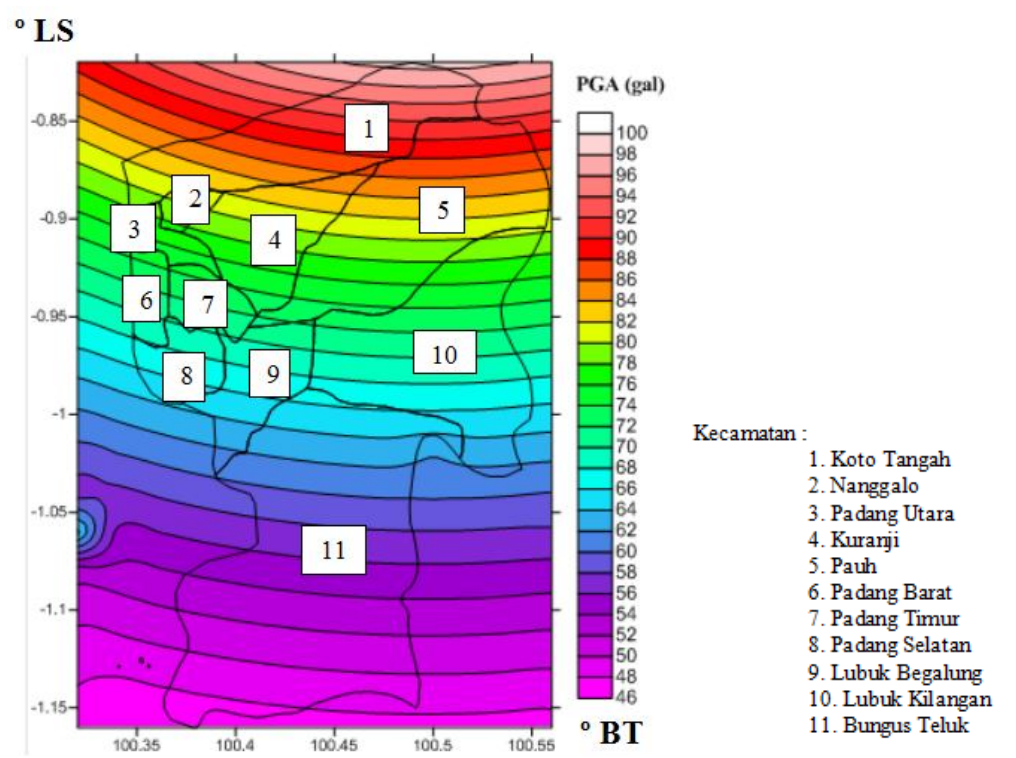

Gambar 2 Peta PGA Kota Padang Sebelum Gempa 30 September 2009.

Nilai percepatan tanah maksimum yang diperhitungkan hanya yang berada di wilayah daratan saja. Nilai tersebut berkisar dari 48,27-94,2 gal. PGA terendah terdapat di Kecamatan Bungus Teluk, sedangkan PGA tertinggi di kecamatan Koto Tangah. Berdasarkan nilai tersebut wilayah Kota Padang dapat dikelompokkan menjadi 2 bagian, yaitu wilayah rawan dan wilayah waspada. Wilayah rawan merupakan wilayah dengan PGA tertinggi yaitu berkisar dari 80,62 
sampai 94,21 gal meliputi Kecamatan Koto Tangah, Nanggalo, Kuranji, dan Pauh. Wilayah waspada memiliki PGA 48,27-79,85 gal meliputi wilayah di luar wilayah rawan.

\subsubsection{Percepatan Tanah Maksimum Kota Padang Sesudah Gempa 30 September 2009}

Banyaknya gempa yang terjadi dari 30 September 2009 sampai 2017 ditunjukkan oleh peta seismisitas gempa pada Gambar 3. Simbol lingkaran pada peta mewakili setiap kejadian gempa di wilayah tersebut, salah satunya kejadian gempa 30 September 2009 dengan magnitudo gempa sebesar 7,6 Mw pada kedalaman $81 \mathrm{~km}$. Sebaran gempa terdiri dari 36 gempa yang berada di sebelah timur Kepulauan Mentawai dan beberapa di Pulau Pagai. Nilai PGA setelah gempa 30 September 2009 diperoleh dari data gempa sesudah gempa 30 September 2009 digabung dengan data gempa sebelum 30 September 2009, sehingga berjumlah 209 data gempa.

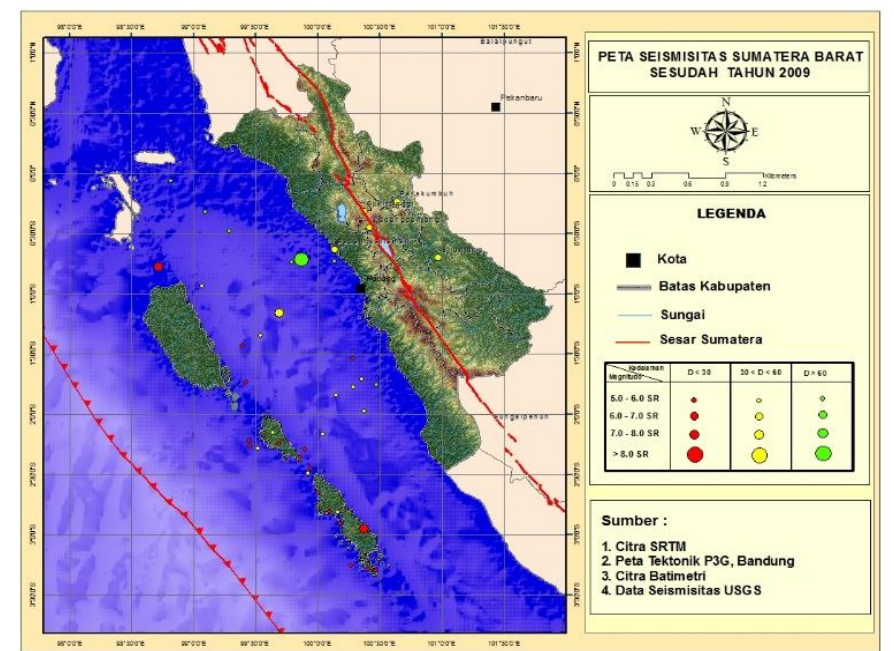

Gambar 3 Peta Seismisitas Gempa di Segmen Mentawai dan Sekitarnya dari 30 September 2009 sampai Tahun 2017.

Nilai PGA dihitung pada 209 data gempa tersebut menggunakan Persamaan 1 di setiap titik grid Kota Padang, sehingga dihasilkan peta percepatan tanah maksimum (PGA) Kota Padang sesudah kejadian gempa besar 30 September 2009 seperti Gambar 4.

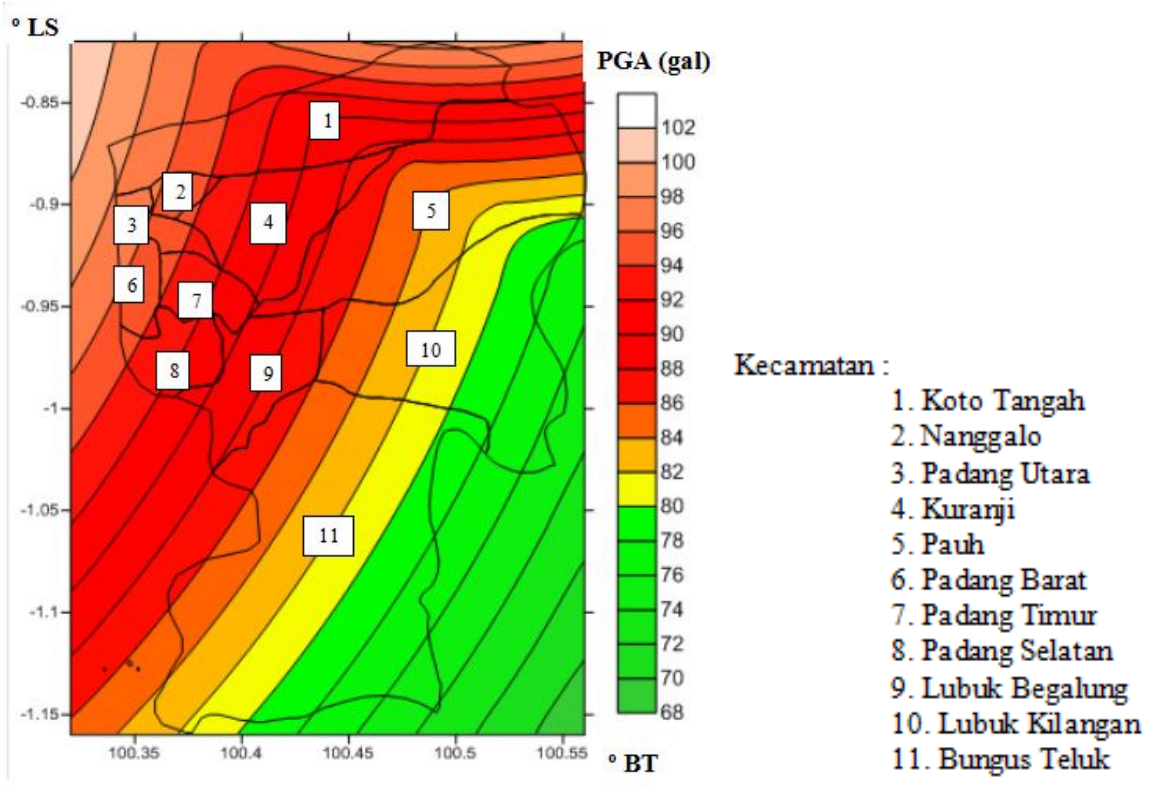

Gambar 4 Peta PGA Kota Padang Sesudah Gempa 30 September 2009. 
Nilai PGA yang diperhitungkan hanya yang di darat saja yaitu berkisar dari 76,10 sampai 96,58 gal. PGA terendah terdapat pada sebagian Kecamatan Bungus Teluk, sedangkan PGA tertinggi terdapat di Kecamatan Koto Tangah, Padang Utara, dan sebagian Kecamatan Padang Barat. Berdasarkan nilai tersebut wilayah Kota Padang dapat dikelompokkan menjadi 2 bagian, yaitu wilayah rawan dan wilayah waspada. Wilayah rawan meliputi hampir ke semua kecamatan di kota Padang dengan PGA diatas 80 gal, sedangkan wilayah waspada dengan PGA dibawah 80 gal meliputi wilayah selain wilayah rawan yaitu hanya sebagian kecil dari wilayah Kecamatan Bungus Teluk dan Lubuk Kilangan.

\subsection{Intensitas Gempa Kota Padang}

\subsubsection{Intensitas Gempa Kota Padang Sebelum Gempa 30 September 2009.}

Intensitas gempa merupakan ukuran tingkat kerusakan yang terlihat di permukaan bumi akibat gempa bumi. Nilai PGA sebelum gempa 30 September 2009 dikonversi ke dalam skala MMI agar diketahui besar intensitas gempanya. Pemetaan intensitas gempa tersebut dapat dilihat pada Gambar 5. Berdasarkan peta tersebut terlihat bahwa sebagian wilayah Kota Padang memiliki intensitas sebesar VI MMI dan sebagian lainnya VII MMI. Intensitas VI MMI terdapat pada Kecamatan Bungus Teluk, Padang Selatan dan sebagian Padang Barat, Lubuk Begalung, dan Lubuk Kilangan, selain kecamatan tersebut berskala VII MMI. Intensitas dengan skala VI akan mengakibatkan beberapa kerusakan ringan seperti keretakan pada bangunan yang kurang baik, sedangkan pada skala VII menimbulkan keretakan pada bangunan dengan kontruksi yang sudah baik.

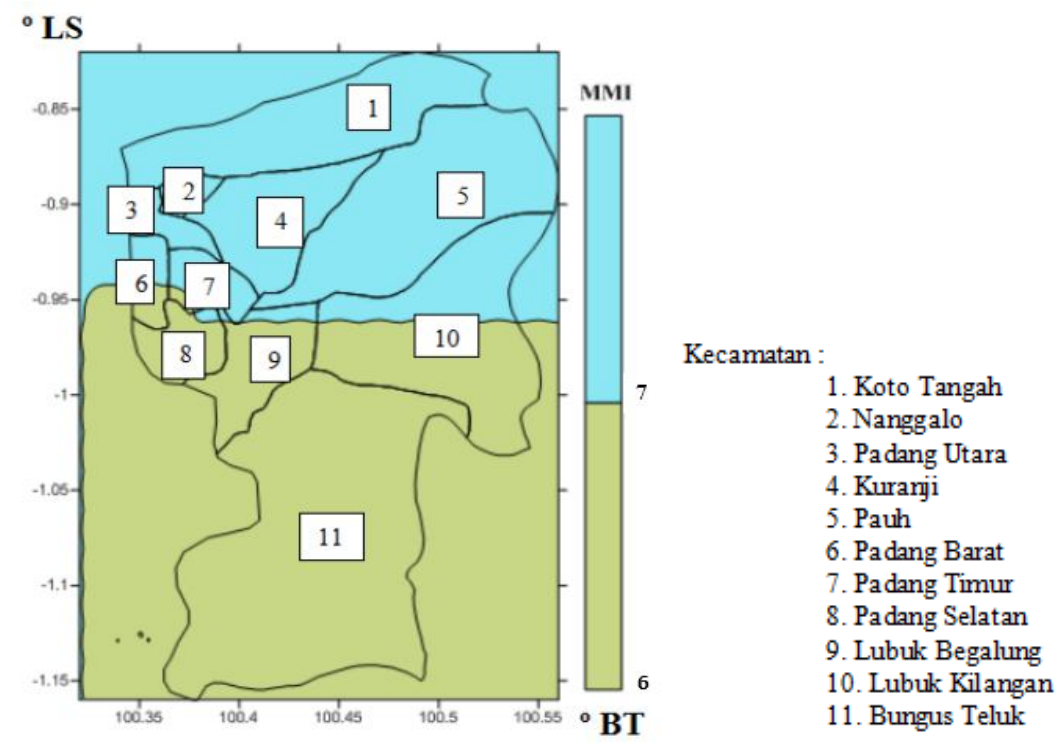

Gambar 5 Peta Intensitas Gempa Kota Padang Sebelum Gempa 30 September 2009.

\subsubsection{Intensitas Gempa Kota Padang Sesudah Gempa 30 September 2009.}

Intensitas gempa sesudah 30 September 2009 diperoleh dari mengkonversi nilai PGA ke dalam skala MMI. Pemetaan ntensitas gempa dapat dilihat pada Gambar 6. Berdasarkan pemetaan terlihat bahwa intensitas gempa sesudah gempa 30 September 2009 berskala VII MMI pada semua wilayah di Kota Padang. Pada Gambar 6 juga terlihat perluasan daerah dengan intensitas VII MMI di Kota Padang dibandingkan dengan Gambar 5 sebelum terjadinya gempa 30 September 2009.

Goncangan gempa yang kuat pada 30 September 2009 dengan magnitudo 7,6 Mw memiliki intensitas VII MMI mengakibatkan kerusakan pada bangunan. Sebagian besar bangunan yang tidak kokoh hancur, sedangkan bangunan dengan konstruksi yang cukup baik mengalami kerusakan. Reruntuhan bangunan juga menimbulkan banyaknya korban jiwa pada gempa tersebut. 

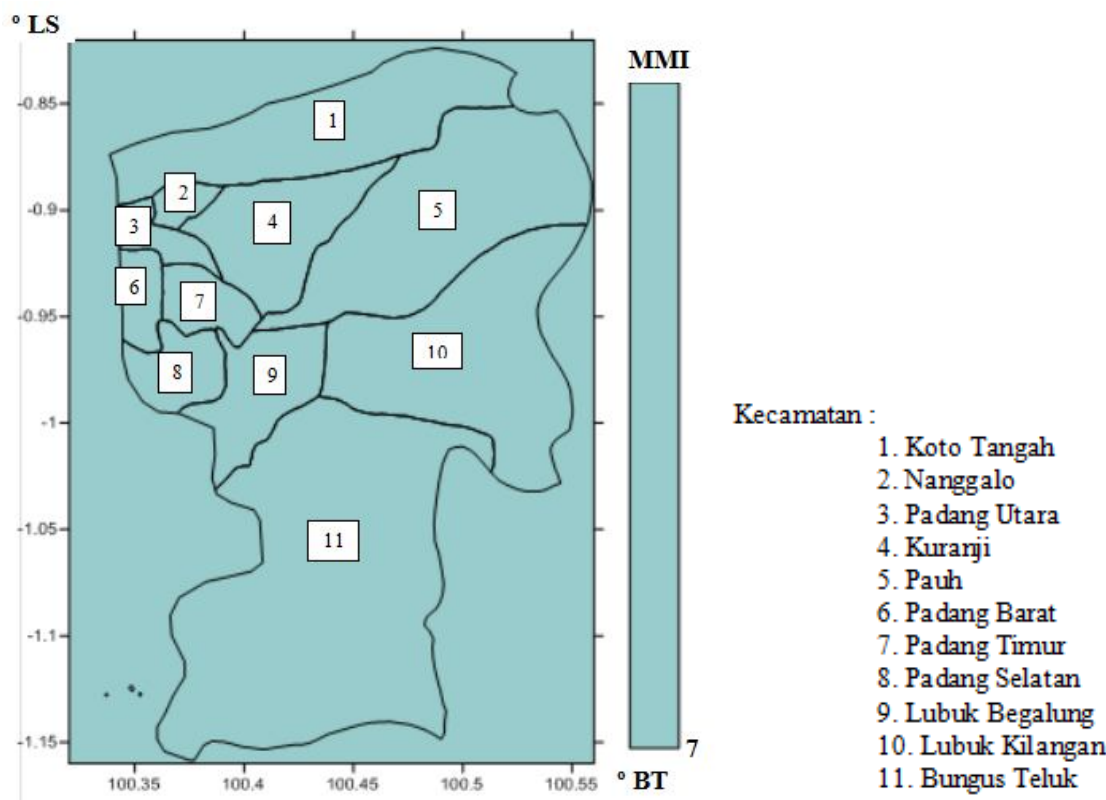

Gambar 6 Peta Intensitas Gempa Kota Padang Sesudah Gempa 30 September 2009.

\subsection{Perbandingan Dampak Gempa Sebelum dan Sesudah Gempa 30 September 2009 di Segmen Mentawai dan Sekitarnya terhadap Percepatan tanah dan Intensitas Gempa Kota Padang.}

Nilai percepatan tanah maksimum Kota Padang sesudah peristiwa gempa besar 30 September 2009 lebih tinggi dibandingkan sebelum gempa. Hal ini karena gempa yang terjadi pada 30 September 2009 sangat kuat dengan hiposenter di laut yang posisinya sangat dekat dengan wilayah daratan Kota Padang yaitu pada koordinat $0,720^{\circ}$ LS dan 99,867 ${ }^{\circ}$ BT. Getaran gempa yang kuat tersebut akan mempengaruhi kondisi kerentanan pada lapisan tanah di Kota Padang. Tanah yang semakin rentan akan cenderung memiliki percepatan yang lebih tinggi saat digoncang gempa berikutnya.

Selisih nilai PGA tertinggi sebelum dan sesudah gempa 30 September 2009 sebenarnya cukup kecil. Hal ini karena sebelum tahun 2009 juga pernah terjadi gempa besar dengan magnitude 7,0 $\mathrm{Mw}$ pada kedalaman 55,5 Km di perairan Sumatera Barat. Episenter gempa tersebut lebih jauh dari wilayah daratan Kota Padang dibandingkan dengan episenter gempa 30 September 2009, sehingga hanya mempengaruhi daerah yang dekat dengan laut. Hal ini jugalah yang menyebabkan perbedaan yang cukup jauh dari nilai PGA terendah yang diperoleh sebelum dan sesudah gempa 30 September 2009.

Intensitas gempa Kota Padang sesudah peristiwa gempa besar 30 September 2009 merata dengan skala VII MMI di semua wilayah kecamatan. Hal ini menunjukkan terjadinya perluasan daerah dengan intensitas VII MMI di Kota Padang setelah terjadinya gempa 30 September 2009. Hal ini juga sebanding dengan nilai percepatan tanah sesudah gempa 30 September 2009 yang tinggi. Besarnya intensitas gempa dapat dibuktikan dengan banyaknya kerusakan pada bangunan sesudah kejadian gempa. Daerah yang dekat dengan laut mengalami kerusakan yang lebih parah dibandingkan daerah yang cukup jauh dari laut. Bangunan yang konstruksinya kurang baik banyak yang hancur, sedangkan yang konstruksinya sudah baik banyak yang retak. Reruntuhan bangunan juga menimbulkan banyaknya orang -orang yang terluka bahkan meninggal dunia.

Kenaikan intensitas gempa yang terjadi pada wilayah Kota Padang dapat menjadi informasi penting dalam perencanaan pembangunan tata ruang dan wilayah yang lebih baik di Kota Padang. Bangunan yang dibangun di semua wilayah di Kota Padang sudah seharusnya memenuhi syarat bangunan yang tahan gempa dikarenakan semua wilayah sudah berada pada intensitas VII MMI, apalagi di wilayah-wilayah yang sudah tergolong waspada karena memiliki nilai PGA yang sangat tinggi. 


\section{KESIMPULAN}

Berdasarkan hasil dan analisa yang diperoleh dari penelitian ini, didapatkan kesimpulan bahwa nilai PGA sebelum gempa 30 September 2009 berkisar dari 48,27-94,2 gal dengan PGA terendah di Kecamatan Bungus Teluk, sedangkan PGA tertinggi di kecamatan Koto Tangah, sedangkan nilai PGA sesudah gempa 30 September 2009 berkisar dari 76,10-96,58 gal dengan PGA terendah terdapat pada sebagian Kecamatan Bungus Teluk, sedangkan PGA tertinggi terdapat di Kecamatan Koto Tangah, Padang Utara, dan sebagian Kecamatan Padang Barat.

Intensitas gempa sebelum gempa 30 September 2009 berskala VI MMI terdapat pada Kecamatan Bungus Teluk, Padang Selatan dan sebagian Padang Barat, Lubuk Begalung, dan Lubuk Kilangan, selain kecamatan tersebut berskala VII MMI, sedangkan Intensitas gempa sesudah gempa 30 September 2009 merata dengan skala VII MMI pada semua wilayah di Kota Padang.

\section{UCAPAN TERIMA KASIH}

Penulis berterima kasih kepada pihak FMIPA Unand yang telah mendanai penelitian ini melalui Dana PNBP FMIPA Unand dengan kontrak penelitian Nomor: 07/UN.15.03.D/PP/FMIPA/2018 tahun anggaran 2018 dan pihak BMKG yang telah banyak membantu dalam penyelesaian penelitian ini.

\section{DAFTAR PUSTAKA}

Edwiza., 2008, Analisis Terhadap Intensitas dan Percepatan Tanah Maksimum Gempa Sumbar, Jurnal Geofisika, Vol. 1, No. 29, Tahun. XV, ISSN: 0854-8471, hal. 73-76.

Edwiza dan Novita., 2008, Percepatan Tanah Maksimum dan Intensitas Seismik Kota Padang Panjang Menggunakan Metode Kanai, Jurnal Geofisika, Vol. 2, No. 29, ISSN: 08548471, hal. 111-118.

Ibrahim, G. dan Subarjo., 2004, Buku Seismologi, BMKG, Jakarta.

Isra, A.M., 2010, Kajian Kebencanaan, Jurnal Teknik Arsitektur, Vol. 1, No. 1, Universitas Bung Hatta.

Kapojos, C.G., Tauntuan, G., dan Pasau, G., 2015, Analisis Percepatan Tanah Maksimum dengan Menggunakan Rumusan Esteva dan Donovan (Studi Kasus Semenanjung Utara Pulau Sulawesi), Jurnal Ilmiah Sains, Vol. 15, No. 2, Jur. Fisika Universitas Sam Ratulangi Manado.

Linkemer., 2008, Relationship Between Peak Ground Acceleration and Modified Mecalli Intensity In Costa Rica, Revista Geologica de America Central, 38ISSN: 0256-7024, hal. 81-94.

Pujiastuti,D., Gustiana,F., Minangsih,M., dan Arifin,H., 2018, Analisis Kecocokan Nilai Percepatan Tanah Kota Padang Berdasarkan Perhitungan Secara Empiris dengan Data Percepatan Tanah dari Akselerograf yang Terpasang di Stasiun Maritim Teluk Bayur Padang, Jurnal Ilmu Fisika, Vol. 10, No. 2, Jur. Fisika Unand.

Sunarjo., Gunawan, M. T., Pribadi, S., 2010, Gempa Bumi Edisi Populer, BMKG, Jakarta. 